\title{
Bereaved spouses' adjustment after the patients' death in palliative care
}

\author{
MARIA E. CARLSSON, S.R.N., ${ }^{1}$ AND INGRID M. NILSSON, S.R.N. ${ }^{2}$ \\ ${ }^{1}$ Department of Public Health and Caring Sciences, Uppsala University, Uppsala, Sweden \\ ${ }^{2}$ Sjukvårdsteamet Kronparksgården, Uppsala, Sweden
}

(RECEIVED October 10, 2006; AcCEPTED January 29, 2007)

\begin{abstract}
Objectives: To improve the support to bereaved spouses during the year after the patient's death, a project was started consisting of three visits by a nurse (after 1, 3, and 13 months) with conversations about the patient's death and the spouse's life situation. The aim of this study was to describe the bereaved spouse's situation and adaptation during the first year after the loss.

Methods: Spouses of patients cared for by The Advanced Home Care Team (APHCT) in Uppsala, Sweden, were invited to participate in the project. Each participant was encouraged to talk freely about his or her situation, but enough direction was given to ensure that all items listed on a standardized questionnaire were covered.

Results: Fifty-one spouses met the inclusion criteria and were invited to participate and 45 accepted. The subjects felt quite healthy but were tired and suffered from sleep disturbance. The grief reactions had initially been high but showed a significant decline from 1 to 13 months $(p<.01)$. Forty-nine percent had experienced postbereavement hallucinations.

Significance of results: This study showed that the bereaved spouses felt quite healthy and adjusted quite well to their new life situation, after the patient's death in a palliative care setting. The grief reactions had initially been high but showed a significant decline during the year.
\end{abstract}

KEYWORDS: Palliative care, Bereaved spouses, Adaptation, Health, Grief reactions

\section{INTRODUCTION}

The loss of a life companion is generally ranked as the most distressing event in person's life (Miller \& Rahe, 1997). Grief often includes emotional, physical, and social reactions. One study reports that widowhood can be associated with an excess risk of psychological morbidity, diabetes mellitus, and dissatisfaction with the economic situation (Valdimarsdottir et al., 2003). A study that investigated how relatives adjust after the death of a patient with cancer (Eriksson et al., 2001) showed that the most common physical symptoms were fatigue and sleeplessness, and the most common mental symptoms were grief, bitterness, and loneliness. Another study by Valdimarsdottir et al. (2002) showed that inefficient psychological

Corresponding author: Maria E. Carlsson, Department of Public Health and Caring Sciences, Uppsala University, Döbelnsgatan 2 S 75237 Uppsala, Sweden. E-mail: maria.carlsson@ pubcare.uu.se symptom control during the last months of the deceased's life may predispose the widows to long-term (i.e., 2-4 year) psychological morbidity. Fakhoury et al. (1997) investigated the association between the physical and psychological well-being of bereaved informal carers and their perceptions of the quality of care the dying patients had received. Those who assessed their health status as excellent were more likely to have been content with the quality of care given. Gilbar's study (1998) reports the finding that a shorter hospice stay (1-7 days) had a beneficial effect on the spouse's bereavement compared to a longer stay ( $8+$ days).

Studies among family members to cancer patients (Chentsova-Dutton et al., 2002; Ringdal et al., 2001) have shown that the grief reactions decline during the first year after the deaths. In Ringdal et al.'s (2001) study, the decline was fairly small, and they suggest that the grieving process starts already before the death, that is, anticipatory grief (Lindemann, 
1944). This explanation is partly supported by Chentsova-Dutton et al. (2002), who found that the levels of psychological symptoms 2 months after the death were equal to or lower than those reported prior to bereavement. Moreover, results from a study by Valdimarsdottir et al. (2004) showed that the awareness time of the husband's impending death was important. They found that the optimal time was 3-6 months, and a very short ( $24 \mathrm{~h})$ awareness time was strongly associated with anxiety and anxiety-related symptoms and moderately associated with depression 2-4 years after the spouse's death.

One cornerstone in palliative care is to offer support to the patient's family during the illness and after the patient's death (World Health Organization Expert Committee, 1990). Bereavement follow-ups are often an ambition after the patient's death, but the support is for the most part unstructured and without clear protocols. A study examining the bereavement follow-ups provided by five palliative support teams in the United Kingdom found that bereavement follow-ups was offered to $67 \%$ of families, but this varied a great deal, from $10 \%$ to $94 \%$, between the teams (Bromberg \& Higginson, 1996). The follow-ups were in form of visits (50\%), telephone contact $(45 \%)$, letters $(3 \%)$, and other contact $(1 \%)$. Valdimarsdottir et al. (2005) investigated the need for bereavement follow-ups in widows of patients who had died of prostate or urinary bladder cancer. They found that two-thirds of the widows would have preferred some formal bereavement support from health caregivers, but that only one out of five had had access to it. Our own study (Rollison \& Carlsson, 2002), which evaluated the Advanced Palliative Home Care Team (APHCT) in Uppsala, Sweden, showed that the next of kin was generally satisfied with the support provided $(90 \%-97 \%)$ but $35 \%$ were dissatisfied with the support after the patient's death.

Grimby (1999) carried out a 1-year support project for 50 bereaved spouses. The intervention consisted of three visits with a semistructured conversation about the patient's death and the spouse's present situation. The subjects were spouses of patients who had died on a geriatric ward. The difficulty varied over the year but the majority thought that the first month after the death was the most demanding. Even 1 year after the death of the spouse, many expressed the need to talk about the time surrounding the death, and every third subject thought that the adaptation to the new situation had not gone well. The most intense reactions were loneliness, anxiety, fatigue, and pessimism about the future.

To improve the support offered to bereaved spouses during the year after the patient's death a project was started in Uppsala, consisted of three visits (after 1, 3, and 13 months). The aim was to give bereaved spouses an opportunity to talk about their experiences during the deceased's last days and death and to talk about their present situation. Besides the visits by a nurse, the spouses were offered support from all the members of the APHCT during the year.

The aim of this study was to describe the bereaved spouses' situation and adaptation during the first year after the loss.

\section{METHODS}

\section{Subjects and Data Collection}

Spouses of patients who had been cared for by APHCT in Uppsala and who had died in their homes or within 2 weeks of admission to in-patient care were invited to participate in the project. One nurse from APHCT conducted all visits. The conversation consisted of dialogues about the patient's death, the spouse's health, grief reactions, socioeconomic situation, exercise and lifestyle, and occurrence of postbereavement hallucinations. Each participant was encouraged to talk freely about their situation; however, enough direction was given to ensure that all items listed on a standardized questionnaire were covered (modification of questionnaires developed by Grimby, 1998). The grief reactions were measured by the second part of the Texas Revised Inventory of Grief (TRIG; Faschingbauer et al., 1987). This second part consists of 13 statements about present grieving and is answered using a 5-point Likert scale ranging from 1 (completely true) to 5 (completely false). At the visits at 13 months an instrument for assessing positive outcomes of trauma, the Posttraumatic Growth Inventory (PGI; Tedeschi \& Caloun, 1996), was used. This instrument consists of 21 items and includes the factors of Relating to others, New possibilities, Personal strength, Spiritual change, and Appreciation of life (Table 1). Respondents were asked to indicate for each of the statements the degree to which the change had occurred as a result of the grief. A 6-point Likert response scale was used ranging from 0 (I did not experience this change as a result of my sorrow) to 5 (I experienced this change to a very great degree as a result of my sorrow). Intermediate scores were given for 1 (to a very small degree), 2 (to a small degree), 3 (to a moderate degree), and 4 (to a great degree).

\section{Setting}

The Uppsala municipality employs one specialized multiprofessional palliative team who serve the whole town and its immediate surroundings. Uppsala's APHCT mainly provide medical care and support 
Table 1. Posttraumatic Growth Inventory (PGI), factors and items

\section{Relating to others}

Knowing that I can count on people in times of trouble. A sense of closeness with others.

A willingness to express my emotions.

Having compassion for others.

Putting effort into my relationships.

I learned a great deal about how wonderful people are.

I accept needing others.

II. New possibilities

I developed new interests.

I established a new path for my life.

I am able to do better things with my life.

New opportunities are available which would not have been otherwise.

I am more likely to try to change things, which need changing.

III. Personal strength

A feeling of self-reliance.

Knowing I can handle difficulties.

Being able to accept the way things work out.

I discovered that I am stronger than I thought I was.

IV. Spiritual Change

A better understanding of spiritual matters.

I have a stronger religious faith.

V. Appreciation of life

My priorities about what is important in life.

An appreciation for the value of my own life.

Appreciating each day.

and is organized based on the Motala model (BeckFriis, 1993).

\section{Data Analysis}

The statistics used for comparisons over time of the TRIG were $t$ test for paired samples and unpaired $t$ test for a comparison between groups. For comparing data at a nominal level and over time McNemars test was used. All tests were conducted at a 5\% significance level.

\section{Ethics}

The study was approved by the Ethical Board at Uppsala University Hospital. The project's aim was to support the bereaved spouses and therefore it was crucial that the conversations would not in any way be experienced as an increase in the burden. All participants were carefully informed about the voluntariness of the project and the possibility to terminate participation in the project at any time and without any explanation. The nurse who conducted all the visits could discuss the subject with, or request involvement of, a psychiatrist who worked in the team.

\section{RESULTS}

Fifty-one spouses met the inclusion criteria and were invited to participate in the project. Forty-five accepted (Table 2 ). Nearly $98 \%$ were positive or very positive about the project when they got the invitation. Two subjects refused the second visit and one refused the third. Nearly $98 \%$ described their marriage as quite or very happy. Responding to the question of how they had coped with strain earlier in life, over $80 \%$ answered quite well or very well. Asked whether they wished they had acted differently before and at the time of the deceased's death, only $16 \%$ said they wished they had. In all cases, the subjects said they wished they had talked more about their feelings and the impeding death and showed the deceased more affection. The time before the spouse's death had been fairly or very trying for $90 \%$ of the spouses, but during the first year following their spouse's death all received a fair to a great amount of support.

\section{Health}

The spouses felt fairly healthy, but $64 \%$ felt tired at the first visit (Table 3). For many, this tiredness, which stemmed from disturbed sleep and sleeplessness, declined during the year $(p<.05$ vs. $p<.01$ ). At the third visit the subjects also made a comparison whether their sleep problems had changed during the last half-year. Of those who had suffered from sleeplessness $40 \%$ said that the problem had increased whereas for $17 \%$, it had decreased.

Table 2. Demographic data of the bereaved spouses $(N=45)$

\begin{tabular}{lc}
\hline \hline Characteristic & $n(\%)$ \\
\hline Gender & \\
Men & $17(38 \%)$ \\
Women & $28(62 \%)$ \\
Age (years) & \\
Mean & 66 \\
Range & $37-84$ \\
Social situation & $39(87 \%)$ \\
Living alone & $6(13 \%)$ \\
Living with a child/children & \\
Employment status & \\
Retired & $27(60 \%)$ \\
Full-time work & $8(18 \%)$ \\
Part-time work & $1(2 \%)$ \\
On sick leave & $7(16 \%)$ \\
Education & \\
Secondary school & $11(27 \%)$ \\
Upper secondary school & $21(47 \%)$ \\
University degree & $6(13 \%)$ \\
Other & $3(7.5 \%)$ \\
&
\end{tabular}

${ }^{\text {a Missing data } n=2 .}$

${ }^{\mathrm{b}}$ Missing data $n=4$. 
Table 3. Perceived health 1, 3, and 13 months after the loss

\begin{tabular}{lccc}
\hline \hline & $\begin{array}{c}1 \\
\text { month }\end{array}$ & $\begin{array}{c}3 \\
\text { months }\end{array}$ & $\begin{array}{c}13 \\
\text { months }\end{array}$ \\
\hline $\begin{array}{l}\text { Good or fairly good health } \\
\quad \text { yes) }\end{array}$ & $71 \%$ & $70 \%$ & $81 \%$ \\
$\begin{array}{l}\text { Physical state (very or } \\
\quad \text { fairly good) }\end{array}$ & $100 \%$ & & $79 \%$ \\
$\begin{array}{l}\text { Fatique (yes) } \\
\text { Insomnia (yes) }\end{array}$ & $64 \%$ & $33 \%$ & $15 \%$ \\
Medicine use (yes) & $43 \%$ & $44 \%$ & $48 \%$ \\
& $89 \%$ & $86 \%$ & $86 \%$ \\
\hline \hline
\end{tabular}

${ }^{\mathrm{a}}$ No measurement at 3 months.

Table 4 shows the participants' physical symptoms during the year, the largest percentages of which were muscular or skeletal. These symptoms did not diminish during the year. Many attributed their pain and tension to the loss, but it is worth noting that we do not know whether the symptoms had appeared in connection with the spouse's illness and death. All other symptoms were relatively constant during the year but on a substantially lower level.

\section{Grief Reactions}

The intensity of grief reactions diminished significantly from 1 to 13 months (Table 5). The single items varied from 1.27 to 3.74 on a 5 -point scale (with high mean values on the TRIG items indicating a low level of grief). The participants' overall grief reactions showed a small but insignificant decline from 1 to 3 months (TRIG 1.78 vs. 2.06), a significant decline from 3 to 13 months (2.06 vs. $2.52 ; p<.05)$, and a great decline from 1 to 13 months (1.78 vs. 2.52; $p<.001)$.

Table 4. Health problems at 1, 3, and 13 months after the loss

\begin{tabular}{lccc}
\hline \hline Problems & $\begin{array}{c}1 \text { month } \\
(n=45)\end{array}$ & $\begin{array}{c}3 \text { months } \\
(n=43)\end{array}$ & $\begin{array}{c}13 \text { months } \\
(n=42)\end{array}$ \\
\hline $\begin{array}{c}\text { Heart and } \\
\text { circulation }\end{array}$ & $6(13 \%)$ & $3(7 \%)$ & $3(7 \%)$ \\
$\begin{array}{c}\text { Lung and } \\
\text { respiration }\end{array}$ & $2(4 \%)$ & $1(2 \%)$ & $2(5 \%)$ \\
$\begin{array}{c}\text { Stomach and } \\
\text { bowels }\end{array}$ & $1(2 \%)$ & 0 & 0 \\
$\begin{array}{c}\text { Urinary tract } \\
\text { Muscular/ } \\
\text { skeleton }\end{array}$ & $1(2 \%)$ & $3(7 \%)$ & $1(2 \%)$ \\
$\begin{array}{c}\text { Unspecific/ } \\
\text { other }\end{array}$ & $11(24 \%)$ & $6(14 \%)$ & $3(7 \%)$ \\
\begin{tabular}{c} 
Sensory \\
\hline
\end{tabular} & $2(4 \%)$ & $1(2 \%)$ & $1(2 \%)$ \\
\hline
\end{tabular}

Table 5. Texas Revised Inventory of Grief (TRIG) over time, with mean score 1, 3, and 13 months after the spouse's death

\begin{tabular}{|c|c|c|c|}
\hline Item & $\begin{array}{c}1 \\
\text { month }\end{array}$ & $\begin{array}{c}3 \\
\text { months }\end{array}$ & $\begin{array}{c}13 \\
\text { months }\end{array}$ \\
\hline $\begin{array}{l}\text { I still cry when I think of } \\
\text { the person who died. }\end{array}$ & 1.88 & 1.97 & $2.82^{* * * *}$ \\
\hline $\begin{array}{l}\text { I still get upset when I } \\
\text { think about the person } \\
\text { who died. }\end{array}$ & 2.29 & 2.76 & $3.21^{* * * *}$ \\
\hline $\begin{array}{l}\text { I cannot accept this } \\
\text { person's deaths. }\end{array}$ & 2.54 & 2.53 & $3.50 * *$ \\
\hline $\begin{array}{l}\text { Sometimes I very much } \\
\text { miss the person who died. }\end{array}$ & 1.29 & 1.44 & 1.61 \\
\hline $\begin{array}{l}\text { Even now it is painful to } \\
\text { recall memories of the } \\
\text { person who died. }\end{array}$ & 1.59 & 2.00 & $2.42^{* * * *}$ \\
\hline $\begin{array}{l}\text { I often think about the } \\
\text { person who died. }\end{array}$ & 1.27 & 1.38 & 1.65 \\
\hline $\begin{array}{l}\text { I hide my tears when I } \\
\text { think about the person } \\
\text { who died. }\end{array}$ & 2.78 & 2.58 & $3.54^{*}$ \\
\hline $\begin{array}{l}\text { No one will ever take the } \\
\text { place in my life of the } \\
\text { person who died. }\end{array}$ & 1.51 & 1.88 & $2.05^{* *}$ \\
\hline $\begin{array}{l}\text { I cannot avoid thinking } \\
\text { about the person who } \\
\text { died. }\end{array}$ & 1.34 & 1.88 & $2.16^{* *}$ \\
\hline $\begin{array}{l}\text { I feel it is unfair that this } \\
\text { person died. }\end{array}$ & 1.75 & 1.73 & 2.16 \\
\hline $\begin{array}{l}\text { Things and people around } \\
\text { me still remind me of the } \\
\text { person who died. }\end{array}$ & 1.32 & 1.32 & $1.84^{* *}$ \\
\hline $\begin{array}{l}\text { I am unable to accept the } \\
\text { death of the person who } \\
\text { died. }\end{array}$ & 2.76 & 2.74 & $3.74^{* *}$ \\
\hline $\begin{array}{l}\text { At times I still feel the need } \\
\text { to cry for the person who } \\
\text { died. }\end{array}$ & 1.49 & 1.82 & $2.16^{* *}$ \\
\hline $\begin{array}{l}\text { Total Texas Revised } \\
\text { Inventory }\end{array}$ & 1.78 & 2.06 & $2.52^{* * * *}$ \\
\hline
\end{tabular}

Note: A high mean score on the TRIG item indicates a low level of grief.

Significant differences compared with 1 month: $*<.05$, $* *<.01, * * *<.001$.

In general, women reported a higher level of grief than men did at 1 month and there were significant differences also for some items (Table 6). However, at 3 months men showed a generally, but not significant, stronger grief reaction than women. At 13 months the women's grief reaction was again stronger. There was only one significant difference related to age, and this was that younger participants showed a stronger reaction than the older participants on the item "I feel it is unfair that this person died" ( $<65$ years 1.25 and $>65$ years $2.24 ; p<.01)$ at 1 months. 
Table 6. Texas Revised Inventory of Grief (TRIG) by gender and over time at 1, 13, and 13 months after the spouse's death

\begin{tabular}{|c|c|c|c|}
\hline Item & $\begin{array}{l}1 \text { month } \\
\text { (men/ } \\
\text { women) }\end{array}$ & $\begin{array}{l}3 \text { months } \\
\text { (men/ } \\
\text { women) }\end{array}$ & $\begin{array}{c}13 \text { months } \\
\text { (men/ } \\
\text { women) }\end{array}$ \\
\hline $\begin{array}{l}\text { I still cry when I } \\
\text { think of the } \\
\text { person who } \\
\text { died }\end{array}$ & $2.06 / 1.68$ & $1.81 / 2.12$ & $3.36 / 2.50$ \\
\hline $\begin{array}{l}\text { I still get upset } \\
\text { when I think } \\
\text { about the } \\
\text { person who } \\
\text { died2 }\end{array}$ & $2.41 / 2.14$ & $2.63 / 3.00$ & $3.50 / 3.04$ \\
\hline $\begin{array}{l}\text { I cannot accept } \\
\text { this persons' } \\
\text { death }\end{array}$ & $2.82 / 2.46$ & $2.50 / 2.72$ & $3.57 / 3.46$ \\
\hline $\begin{array}{l}\text { Sometimes I very } \\
\text { much miss the } \\
\text { person who } \\
\text { died }\end{array}$ & $1.59 / 1.07^{*}$ & $1.25 / 1.52$ & $2.07 / 1.33^{*}$ \\
\hline $\begin{array}{l}\text { Even now it is } \\
\text { painful to recall } \\
\text { memories of the } \\
\text { person } \\
\text { who died }\end{array}$ & $1.59 / 1.54$ & $1.75 / 2.20$ & $2.43 / 2.42$ \\
\hline $\begin{array}{l}\text { I often think } \\
\text { about the } \\
\text { person who } \\
\text { died }\end{array}$ & $1.41 / 1.19$ & $1.25 / 1.40$ & $2.36 / 1.21^{* *}$ \\
\hline $\begin{array}{l}\text { I hide my tears } \\
\text { when I think } \\
\text { about the } \\
\text { person who } \\
\text { died }\end{array}$ & $2.53 / 2.96$ & $2.75 / 2.84$ & $3.38 / 3.63$ \\
\hline $\begin{array}{l}\text { No one will ever } \\
\text { take the place } \\
\text { in my life of the } \\
\text { person } \\
\text { who died }\end{array}$ & $1.76 / 1.07 * *$ & $1.44 / 1.92$ & $2.71 / 1.67^{*}$ \\
\hline $\begin{array}{l}\text { I can not avoid } \\
\text { thinking about } \\
\text { the person who } \\
\text { died }\end{array}$ & $1.47 / 1.46$ & $2.06 / 1.76$ & $2.36 / 2.04$ \\
\hline $\begin{array}{l}\text { I feel it is unfair } \\
\text { that this person } \\
\text { died }\end{array}$ & $1.71 / 1.86$ & $1.88 / 1.96$ & $2.43 / 2.00$ \\
\hline $\begin{array}{l}\text { Things and people } \\
\text { around me still } \\
\text { remind me of } \\
\text { the person } \\
\text { who died }\end{array}$ & $1.35 / 1.32$ & $1.50 / 1.32$ & $2.14 / 1.67$ \\
\hline $\begin{array}{l}\text { I am unable to } \\
\text { accept the } \\
\text { death of the } \\
\text { person who } \\
\text { died }\end{array}$ & $3.12 / 2.57$ & $2.75 / 2.96$ & $3.64 / 3.79$ \\
\hline $\begin{array}{l}\text { At times I still feel } \\
\text { the need to cry } \\
\text { for the person } \\
\text { who died }\end{array}$ & $1.82 / 1.21^{*}$ & $1.88 / 1.88$ & $2.86 / 1.75^{*}$ \\
\hline
\end{tabular}

Continued
Table 6. Continued

\begin{tabular}{lccc}
\hline \hline Item & $\begin{array}{c}1 \text { month } \\
\text { (men/ } \\
\text { women) }\end{array}$ & $\begin{array}{c}3 \text { months } \\
\text { (men/ } \\
\text { women) }\end{array}$ & $\begin{array}{c}13 \text { months } \\
\text { (men/ } \\
\text { women) }\end{array}$ \\
\hline $\begin{array}{l}\text { Total Texas } \\
\text { Revised } \\
\begin{array}{l}\text { Inventory of } \\
\text { Grief }\end{array}\end{array}$ & $1.97 / 1.73$ & $1.96 / 2.13$ & $2.83 / 2.35$ \\
& & & \\
\end{tabular}

Note: A high mean score on the TRIG item indicates a low level of grief.

Significant differences compared the other gender: $*<.05$, $* *<.01$.

\section{Postbereavement Hallucinations}

Forty-nine percent of participants had experienced postbereavement hallucinations, mostly in the form of hearing $(n=13)$, feeling the presence of $(n=9)$, seeing $(n=6)$, and speaking with $(n=2)$ the deceased. It was common to hear the footsteps of the deceased or hear the deceased shout the spouses' name from an adjacent room. This feeling of the deceased being present could be experienced as the well-known smell of the husband/wife or as the deceased laying beside the spouse in the double bed. For some, the postbereavement hallucinations were natural and welcome, but for most of participants the feeling of loneliness was even stronger afterward. Only four subjects were certain, in contrast to 15 who was uncertain, that the postbereavement hallucination had helped them in their mourning.

\section{Social Life, Interests and Lifestyle}

All participants felt that they had a fair or great amount of support during the year after the loss. By the 13-month visit, all participants were interested in topics of current interest (Table 7). Most had some or quite a few friends to keep them company. For 16, the need to meet up with friends had increased the last half-year, whereas it had decreased for 1 and was unchanged for the rest. The majority of participants believed in God and for 5 their faith had increased. However, only a few were interested in taking part in parish activities, including 4 who reported increased interest, whereas 1 had lower interest in such activities compared with before the death of the deceased.

The majority had not changed their lifestyle much, either at 3 or 13 months (Table 8). The largest change was that 12 persons had increased the amount of exercise they did by the time we conducted the last visit. Regarding eating, smoking, and alcohol 
Table 7. Social life and interests in subjects 13 months after the loss

\begin{tabular}{lrr}
\hline \hline Social life/interests & yes & no \\
\hline Topics of current interest & $100 \%$ & \\
Domestic animal & $40 \%$ & $60 \%$ \\
Friend/s (one to four friends) & $98 \%$ & $2 \%$ \\
Church & $33 \%$ & $67 \%$ \\
Faith in God & $66 \%$ & $33 \%$ \\
& & \\
\hline \hline
\end{tabular}

use, more participants had decreased rather than increased these.

\section{Adjustment to the New Situation}

At 3 months, $69 \%$ had a positive or mostly positive outlook to the future and this had increased to $83 \%$ by 13 months after the loss. At this time, the majority $(93 \%)$ thought that they had adjusted well or fairly well to single life. Finances were no big problem, with most participants (88\%) expressing no worry about their finances and the rest expressing only some anxiety. For some, finances had even improved, as the deceased had planned for the bereaved. With regard to the question of whether the loss had caused any positive changes, the greatest positive changes were the relating-to-others factor and the personalstrength factor, whereas the spiritual change factor had changed little (Table 9). The grief had made the participants appreciate relationship with other people. The loss had forced many to do things they had never done in their marriage, such as solving practical problems, taking care of finances, and traveling on their own. Succeeding in this was a positive experience for some.

\section{DISCUSSION}

The participants' adaptation to the new situation gave a fairly encouraging picture, with most subjects
Table 9. Posttraumatic Growth Inventory (PGI) at 13 months after the loss

\begin{tabular}{lcrrr}
\hline \hline Factor & Max score & Men & Women & Total \\
\hline I. Relating to others & $(35)$ & 15.1 & 16.3 & 15.9 \\
II. New possibilities & $(25)$ & 7.6 & 8.5 & 8.2 \\
III. Personal strength & $(20)$ & 8.0 & 10.8 & 9.8 \\
III. Spiritual Change & $(10)$ & 1.6 & 2.9 & 2.4 \\
IV. Appreciation of life & $(15)$ & 7.7 & 6.3 & 6.7 \\
& & & & \\
\hline
\end{tabular}

having a relatively positive outlook on the future and all being interested in current events and trying to be up to date with what was happening in the world. They also tried to meet their friends often. This interest was also reflected in the PGI score, where the biggest positive changes occurred in the relating-toothers and personal-strength factors. The finding that bereavement can also be associated with something positive is in agreement with the conclusion of the literature review by Chentsova Dutton and Zisook (2005). Most subjects in the present study adapted better to the loss compared with bereaved spouses in Grimby's study (1999), which had a similar design but was performed in a geriatric context. In her study, the most frequent feelings experienced 1 year after the loss were loneliness, sadness, and anxiety. The subjects in Grimby's study also expressed greater pessimism about the future and more financial worries. One plausible explanation for this is that the subjects in the present study were younger than in Grimby's study and therefore had a larger social network. The results of the present study were in better agreement with a study conducted after the death of patients at a Finnish hospice (Eriksson et al., 2001).

Regarding the present subjects' health, our findings are in agreement with the findings in Grimby's (1999) study. The majority of subjects felt fairly healthy but tired 1 month after the loss, and their tiredness gradually decreased thereafter. The

Table 8. Lifestyle changes 3 months and 13 months after the death

\begin{tabular}{|c|c|c|c|c|c|c|c|c|}
\hline \multirow[b]{2}{*}{ Lifestyle item } & \multicolumn{2}{|c|}{$\begin{array}{c}\text { Teetotaller/ } \\
\text { nonsmoker }(n)\end{array}$} & \multicolumn{2}{|c|}{ No change $(n)$} & \multicolumn{2}{|c|}{$\uparrow(n)$} & \multicolumn{2}{|c|}{$\downarrow(n)$} \\
\hline & 3 months & $\begin{array}{c}13 \\
\text { months }\end{array}$ & 3 months & $\begin{array}{c}13 \\
\text { months }\end{array}$ & 3 months & $\begin{array}{c}13 \\
\text { months }\end{array}$ & 3 months & $\begin{array}{c}13 \\
\text { months }\end{array}$ \\
\hline Exercise & & & 28 & 23 & 4 & 12 & 9 & 6 \\
\hline $\begin{array}{l}\text { Eating habit (more or } \\
\text { less) }\end{array}$ & & & 28 & 31 & 5 & 4 & 9 & 9 \\
\hline Alcohol use & 3 & 4 & 36 & 34 & 0 & 1 & 2 & 3 \\
\hline Smoking habit & 18 & 23 & 19 & 17 & 1 & 0 & 1 & 2 \\
\hline
\end{tabular}


sleeplessness, on the another hand, increased during the year. A study by Carter (2005) showed that bereaved caregivers suffer from severe levels of sleep disturbance, with prolonged time to fall asleep, short sleep duration, and poor sleep efficiency. The most common physical concerns were muscular and skeletal, and this problem, if anything, increased rather than decreased during the year. Some subjects regularly visited a masseur or a physiotherapist and thought this helped them.

Almost half of the subjects had had postbereavement hallucinations, a considerably lower percentage than the $82 \%$ reported in Grimby's (1993) study. The finding that only four (19\%) subjects with postbereavement hallucinations in the present study found them pleasant was unexpected, because other studies have reported such hallucinations as mainly pleasant experiences (Rees, 1971; Olson et al., 1985; Grimby, 1993). What the spouses thought was especially negative about postbereavement hallucinations was that the grief increased afterward, when they realized that the deceased had not returned but that this had been an illusion.

Female subjects reported a higher level of grief at 1 month and 13 months whereas male subjects experienced a slightly higher level of grief at 3 months. We have no explanation for this pattern, except that the grief reaction may have been partly delayed in the men. Ringdal et al.'s (2001) study showed female subjects had significantly stronger grief reactions at every measurement (at 1, 3, 6, and 13 months) compared with male subjects. In Chentsova-Dutton et al.'s (2002) study, on the other hand, men tended to report higher levels of grief than women at every measurement (at 2, 7, and 13 months). Why the results are so divergent in different studies is hard to explain, except that the measurements were done at slightly different times and the groups of bereaved subjects were different. Whereas the study by Chentsova-Dutton et al. (2002) also included adult children of the deceased, Ringdal et al.'s (2001) study included adult children, siblings, and friends apart from the spouse.

\section{ACKNOWLEDGMENT}

This study was supported by grants from the Swedish Cancer Foundation.

\section{REFERENCES}

Beck-Friis, B. (1993). Hospital based home care of terminally ill cancer patients. The Motala model. Thesis, Uppsala University.
Bromberg, M.H. \& Higginson, I. (1996). Bereavement follow-up: What do palliative support teams actually do? Journal of Palliative Care, 12, 12-17

Carter, P. (2005). Bereaved caregivers' descriptions of sleep: Impact on daily life and the bereavement process. Oncology Nursing Forum, 32, E70-E75.

Chentsova-Dutton, Y., Shucter, S., Hutchin, S., et al. (2002). Depression and grief reactions in hospice caregivers: From pre-death to 1 year afterwards. Journal of Affective Disorders, 69, 53-60.

Chentsova-Dutton, Y. \& Zisook, S. (2005). Adaptation to bereavement. Death Studies, 29, 877-903.

Eriksson, E., Somer, S., \& Lauri, S. (2001). How relatives adjust after the death of a patient with cancer in hospice. Cancer Nursing, 24, 436-445.

Fakhoury, W., McCarty, M., \& Addington-Hall, J. (1997). Carers' health status. Is it associated with their evaluation of the quality of pallaitive care? Scandinavian Journal of Social Medicine, 25, 296-301.

Faschingbauer, T.R., Zisook, S., \& De Vaul, R. (1987). The Texas Revised Inventory of Grief. In Biopsychosocial Aspects of Bereavement. Progression in Psychiatry, Zisook, S. (ed.), pp. 109-124. Washington, DC: American Psychiatric Press.

Gilbar, O. (1998). Length of cancer patients' stay at a hospice: Does it affect psychological adjustment to the loss of the spouse? Journal of Palliative Care, $14,16-20$.

Grimby, A. (1993). Bereavement among elderly people, grief reactions, postbereavement hallucinations and quality of life. Acta Psychiatrica Scandinavica, 87, $72-80$.

Grimby, A. (1998). Utveckling av stöd- och rådgivningsenhet för äldre nyblivna änkepersoner. Medicinsk, psykologisk och social intervention under Aret efter förlusten. Slutrapport till Socialstyrelsen. (Spriline - U 30385).

Grimby, A. (1999). Stöd och rådgivning underlättar i sorgen. Interventionsprojekt bland äldre nyblivna änkor och änklingar i Göteborg. Läkartidningen, 96, 1838-1842.

Lindemann, E. (1944). Symptomatology and management of acute grief. American Journal of Psychiatry, 15, $155-160$.

Miller, M.A. \& Rahe, R.H. (1997). Life changes scaling for the 1990. Journal of Psychosomatic Research, 43, 279-292.

Olson, P., Suddeth, J., Peterson, P., et al. (1985). Hallicinations of widowhood. Journal of the American Geriatrics Society, 33, 543-547.

Rees, W. (1971). The hallucination of widowhood. British Medical Journal, 4, 37-41.

Ringdal, G., Jordhoy, M., Ringdal, K., et al. (2001). Factors affecting grief reactions in close family members to individuals who have died of cancer. Journal of Pain and Symptom Management, 22, 1016-26.

Rollison, B. \& Carlsson, M. (2002). Evaluation of advanced home care (AHC). The next-of-kins' experiences. European Journal of Oncology Nursing, 6, 100-106.

Tedeschi, R.G. \& Caloun, L.G. (1996). The Posttraumatic Growth Inventory: Measuring the positive legacy of trauma. Journal of Traumatic Stress, 9, 455-471.

Valdimarsdottir, U., Helgason, A.R., Fürst, C.J., et al. (2002). The unrecognised cost of cancer patients' unrelieved symptoms: A nationwide follow-up of the surviving partners. British Journal of cancer, 86, 1540-1545. 
Valdimarsdottir, U., Helgason, A.R., Fürst, C.J., et al. (2003). Long-term efffects of widowhood after terminal cancer: A Swedish nationwide follow-up. Scandinavian Journal of Public Health, 31, 31-36.

Valdimarsdottir, U., Helgason, A.R., Fürst, C.J., et al. (2004). Awareness of husband's impending death from cancer and long-term anxiety in widowhood: A nationwide follow-up. Palliative Medicine, 18, 432-443.
Valdimarsdottir, U., Helgason, A.R., Fürst, C.J., et al. (2005). Need for and access to bereavement support after loss of a husband to urologic cancers: A nationwide follow-up of Swedish widows. Scandinavian Journal of Urology and Nephrology, 39, 271-276.

World Health Organization Expert Committee on Cancer Pain and Active Support Care. (1990). Cancer pain relief and palliative care: Report of a WHO expert committtee. Geneva: World Health Organization. 